,,darap gerichte samenwerking van schenker en begiftigde in , le macht van deze is overgegalu en tijjens dien overgang de , wilsovereenstemming on te schenken en ten geschenke aan te ,nemen bestaat, terwijl nict terzalic doet, dat die wilsoveroen„stemming reeds korter of langer tevoren is ontstaan."

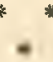

M.i. wordt in dit arrest geleerd, geheel in strijd met het standjunt in het bowen besproken arrest van 17 Juni 1932 ingenomen, dat het voor de beordecling van de geldighcid eencr schenking van ecu roerende zaak aankont op de zikelijke overeenkonst, de levering, en dat het deze overeenkomst is, welke art. $1724 \mathrm{~B}$. W. op het oog heeft. 'Tevens wordt daardoor an? art. $172+$ 13. W. een zecr ruine werking toegekend. Nict slechts de zoogenaande gift van hand tot hand van een rocrende zaak, maar elke eigendomsoverdracht van zulk een zaak, wolke met schenkingshedoeling plats vindt, wordt volgens deze opvatting, door art. $1724 \mathrm{~B}$.W. beheerseht. Best mogelijk, dat aan de eigendomsoverdracht met sehenkingsbedoeling ecn schenkingsovercenkomst voorafgat, maar dit is voor de beordecling van de geldigheid der schenking van geen gewicht. Waar het op aankomt is, dat tijdens den overgang van het gesehonkene, de wilsoverecnstemming om te schenken en ten geschenke aan te nemen bestaat." Een schenkingsovereenkomst van roerend goed, d.i. een overcenkoust waarbij iemand zich verbindt om aan een ander een roerende zak om niet af te staan, behoeft naar deze leel dus niet bij notaricele akte te gesehieden. Als maar te ecniger tijd de overdracht van het geschonkene plats vindt, is er" al.sdan een geldige schenking. In art. 1724 P. W. zal men. als volgt hebben te lezen : Elke cigendomsoverdiacht door feitelijke ter handstelling met schenkingsbedocling van rocrende lichamelijke voorwerpen of van schuldvorderingen aan toonder, is geldig zonder notaricele akte.

\section{* *}

Wij mecnen in alle bescheidenheid, dat deze opvatting in strijd is met de wet. Zeker, ook wij ziju van mecning, dat art. 1724 B. W. regelt de schenking, welke door de eigendomsoverdracht zelve, de zakelijke overcenkomst, geschicdt; dat dit artikel ook in dat opzicht cen uitzondering vormt op art. $1703 \mathrm{~B}$. $\mathrm{W}$., hetwelk heel in het algemeen de schenking als obligatoire overecnkomst, als cen overeenkomst verplichtend tot levering om nict, regelt. Maar onjuist komt het ons voor om op de eigendomsoverdracht van een roerende zaak, welke plaats vindt krachtens een daaraan voorafgegaan sehenkingscontract, de bepaling van art. $1724 \mathrm{~B}$. W. toe te passen. Want in zulk cen geval is, anders dan bij de gift van hand tot hand, de schenkingshandeling niet gelegen in de overdracht der zaak zelve, maar in het schenkingscontract, krachtens hetwelk later moct worden overgedragen. De overdracht zelve der geschonken zaak is alsdan geen schenling, maar het voldoen aan een verbintenis, $m$. a.w. cen betaling. De schenker, dic uitvoering gceft aan een schenlingeontract, verrieht nict opnieuw een schenkingshandeling, maar kont ecnvoudig zijn contractueele verplichting tegenover den begiftigde na. Fn daarom kan m.i. art. 1724 B.W., zoomin als welke bepaling over schenking ook, daarop toepasselijk zijn.

\section{Chr. ZEVENBERGEN}

\section{EEN NIEUW ORGAAN}

Onlangs is een ,Advicsbureau en inlichtingsdienst inzake kantoormachines" door het "Raadgevend kantoor voor Organisatie en Efficiency", alhier, in het leven geroepen, een ge- beutenis, die nar wij menden in hot M.A.B. verdiende besproken te worden. Nict, om den lezers aan to bevelen van dit bureau, dezen dienst, geb)uik te maken; dit ligt niet op onzen weg. Doch wel, ondat hier icts gebeurde, wat typeerend is voul de richting, walarin zich in de lailste 20 jaren de technick van het kantoor, in den ruimsten zin genomen, bewoog. De machine, die eerst in de voorthrenging het handwerk verdrong, begon het in onze ecuw in de arlministratie te doen. Ook daar bleck, dat zeer vele verrichtingen met grooter nuttig effect gehecl of ten decle konden worden gemechimiseerd. Fin naar mate met den groei, de uitbreiding en de concentratic der bedrijven de kantoren in omvang tocnamen, velmecterden de pogingen en de mogelijkheden tot aanwending van mechanische krachten aldaar.

Wat aanvankelijk met het gebuik maken van een enkele machine begon (en vaak lang blecf), ontwikkelde rich gelcidelijk en in stoeds sncller tempo tot cen systematische, organische toepassing van vele. Meer en meer werden de handelingen in liet kantoor geanalysecrd en werd in aansluiting daaraan naar malchines gezocht, die den arbeid konden overnemen. De industrie, aangelokt door dit nicuw terrein van mogelijkheden, bood mot den voortgang dier ontwikkeling voor ieder onderdeel der administratie \%ulk een verseheidenheid van machines en werktuigen aun, dat zonder deskundigheid de keus voor het publick ondoenlijk bleck. Parallel hiermede ontwikkelde zich ecn soort wetensehap der kantoorinrichting, ecnerzijds, onder den invloed der mechanisatic, anderzijds, in verband met de eisehen, dir van de zijcle van het in dicn zelfden tijd tot groote ontwikkeling komende accountantslyeroep aan een goede bockhouding werken gestcld. Dit proces ging in de laatste jarcn met zulk cen vaart, dat het voor den accountant, die toch alleleerst gerocpen was advies te geven bij plannen tot mechanisatic der administratic, problecm werd, hoc bij te blijven. Fis' ging ,,te veel tijd inzitten"'. En hoewel de grootcre accountantskantoren uiteraard zich op min of neer efficiënter wijze dan de kleinere er op konden inrichten - en dit ook deden - om het nieuwo kritisch te ziften, toch werd ook daar al levendiger beseft, dat men slechts ,half werk" deed. Meer en meer werd het in de accountantswereld communis opinio, dat hier ecn vruchthaar terrein voor arbeidsverdeeling gegeven was en werd de behoefte levendig a cen organ, dat op objectieve wijze, buiten den invloed van den uiteraard nict objectieve verkoopers, inlichten kon over alles, wat op het terrein der mechanisatie der administratie versehen en met kennis van zaken het wardevolle van het onbelangrijke scheiden kon. Te zaak had voor den accountant zelfs een tweezijdig belang. Het bleek n.l. al spoedig, dat de omwenteling in de inrichting der boekhouding nict zonder invloed kon blijven op de controletechniek. M.a.w. het werd voor den aceountant nict slechts van belang als adviseur van zijn cliënt op de hoogte te zijn van de mechanisatie-mogelijkheden in de bockhouding. doch nict minder, te weten, welk gebruik hij bij zijn arbeid als contrôleur van do machine maken kon. Het is dan ook begrijpelijk, dat recls voor meer dan 10 jaren een commissie uit de accountantswercld voorstellen heeft gredaan, on tot cen organisatie te komen, die de leclen van het N. I. v. A. van roorlichtiner ter zake zou kmmen dienen. Het in dat advies gedachte burean is toen niet tot stand gekomen. Datuna is het onderwerp ,nict van de lucht" geweest: (Op den 19den accountantsdag van het Instituut werd er aan de hand van cen referat van een der leden een uitvoerige bespreking aan gewijd. In 1932 kwam het in een ,ledenbijeenkomst" nogmaals in debat.

Het in den anvang genoemde Raadgevend Kantoor, zond ons cen overzicht van hetgeen in referaten en debatten bij de beide laatstgenoemde gelegenheden werd opgemerlit met een samenvatting der conclusies, die wij vanwoge het belang der zadk hier willen overnemen: 
1. De mechanisatie van de administratie bchoort tot het terrein van den accountant.

2. Wannecr de aceountant bij de mechanisatic leiding wil geven, is het noodig, dat hij een grondige kemnis van de moderne arbeidsmethoden en moderne hulpmiddelen bezit.

3. De groote verscheidenheid der moderne hulpmiddelen en de nog dagelijks plaats vindende veranderingen maken het den aceountant echter buitengewoon mocilijk dit gelbied to beheersehen.

4. Wel kim men vrij gemakkelijk een zekere algemeene kennis over de moderne hulpmiddelen krijgen. 1)e\%o kennis is echter voor de practische invoering en toepassing dezer hulpmiddelen onvoldoende.

5. Dit gemis tracht men in het algemeen an te vullen loor bij het nitwerken der problemen de hulp van één of meer kantoormachine-handelaren in te roepen. Idealal is de\%e oplossing echter niet.

6. Als gevolg van één en ancler kan men eonstatecren, dat de aceountant in het algemeen op het gebied van de mechanisatic nog niet de plaats inneemt, die hem overeenkomstig lyet in punt 1 gestelde toekomt.

7. Reels tien jaar geleden zijn pogingen gedaan dit envel cloor het oprichten van een centraal advies. bureau op te heffen.

8. 'Tot nog toe is daarvan cchter om versehillende redenen nog niets gekomen. II et belangrijkste bezwalar lag wel in de kosten, die de voorgestelde organisatie voor het Tnstituut zou veroorzaken.

9. Door tal vam accountants wordt cen advicsbureau echter nog steeds wensehelijk geacht.

10. Door specialisatic kan in deze behoefte worden voorzien.

I)at hot lang gewenseht orgalan thans gekomen is, mag een verblijglende gebeurtenis worden genoemd on als wij hier den initiatiefnener gelukwenschen met zijn onderneming, dan is dit in de cerste plaats in do overtuiging, dat het accountantsberoep met zijn werk wezenlijk kan worden gebaat.

C. V.

\section{UIT DE FINANCIEELE HUISHOUDING DER OVERHEID}

Red.: J. H. TEXTOR

(Bijdragen en mededeelingen zende men aan den Secretaris der Redactie)

\section{Taxatie bij grondbedrijven.}

I.

De omstancligheid, dat in dezen tijal van depressie de waarde van gronden in het algemeen daalt, plaatst vele gemeenter, die er uit hoofde van verschillende crisisomstandigheden werkloosheidszor'o, dalende helastingen enz. - financiee? toch al niet gunstig voorstaan, veclal voor groote moeilijkheden. Wij hebben hier het oog op die gemeenten, die het financieel beheer dier gronden, welke in het algemeen voor. belooluing zijn hestend, afzonderlijk hebben geregeld door daarvoor een grondhedrijf in te stellen. Ileeft bij de instelling over dit bedrijf dikwijls ook de bedocling voorgezeten om de gemeente financied nict in aroote mocilijkheklen te brengen. in den tegenwoordigen tijd blijkt lhet grondbedrijf veelal juist het tegendeel te veroolzaken van wat in den aanvang werd beoogd. Dit is een gevolg van de veiligheidsbepaling, die in de meeste verordeningen op liet beheer van dat hedrijf is vastgelegd, 11.l., dat de gronden cens in de vijf jaren moeten worlen getaxeerd en dat het nadeelig verschil, dat dan tus. schen de boekwarle en de taxatiewa arde dier gronden blijkt te bestaan, door de gemeente uit hare gewone middelen moet worden gedekt, voor zoover de bij het bedrijf gevormde reserves daartoe niet voldoende zijn. Gelukkig die gemeenten, die now den tijd heblen met taxeeren! Vele zijn dit echter niet, gerien den hierbovengenoenden termijn van vijf jaren en den tijd, gedurende welken de invloed vall de erisis merkbaar is.

In de hierroor vermelde omstandigheid en het feit, dat onlangs een interessant proefschrift aan de grondpolitiek dor Gemeente Amsterdam werd gewijd ${ }^{1}$ ), vinden wij de vrijheid om voor dic lezers, die net den financieelen kant van de gemeentelijke arondpolitiek niet op de hoogte zijn, hierna eene behandeling te laten volgen van de financiering der gemeentelijke grondbedrijven, warbij wij, na eene algemeene besprekine dier hedrijven, speciaal aandacht zullen wijden aan de genoende moeilijkheden en de wijzen, waarop men deze tracht (met den nadruk op dit woord) te ondervangen.

De uithreiding van de bevolking on als gevolg darvan de toenemende bebouwing stelden de gemeenten voor de vraag, op welke wijze het hest kon worten voorzien in eene zoodanige stadsuithreiding, dat hygienische en andere belargen niet zouden worden verwaarloosd. IIet is duidelijk, dat van het particulier initiatief alleen niet kon worden verwacht, dat met al deze vitale helangen genoegzam rekening zou worden gehouden. Men denke bijv. aan het vrijhouden van terreinen voor bouw van arbeiderswoningen, plantsoenes, scholen, e.d. Fen gemeentelijk uithreidingsplan verschaft in dit opzicht geen voldoenden warrborg, zoodat grondaankoop door de gemeente voor de hand lag. Daarbij komt, dat, indien de onemte voldoencle bouwrijpen grond voor uithreiding tot hare beschikling heeft, de waardevermeerdering, die van do bouwplannen het gevolg is, niet in handen valt van particuliere grondspeculanten maar van de gemeenschap. Wel is hierloij echter te bedenken, dat de overheid dan de taak van de speculanten overneemt met alle risico's van dien, gelijk thans maar al te vaak blijkt.

Fen grondpolitiek, die wordt gevoerd, zooals hierboven is aangegeven, eischt echter een groote som gelds. Daar de gemeenten in het algemeen niet over veel vrij kapitaal beschikken, zullen de noodige middelen, die roor aankoop en bouwrijp maken van gronden noodig zijn, uit lecningen moeten worden gevonden.

Filk jaar zal van deze leeningen een gedeelte moeten worden afuelost; olk jaar zal de gemente tevens voor de noodzakelijkheid plaatsen om de rente der geleende gelden te voldoen. Feitelijk is de financiering nit leeningen voor de gemeente terzake van haar grondpolitiek niet de meest aangewezene; zij zou zich kapitaal noeten verschaffen onder de voorwarde om af te lossen, indien de grondverkoopen dit zouden veroorlooven of, voor zoover zij zich voorstelt om de bouwrijpe gronden later in erfpacht uit te geven, zelfs zonder de verplichting tot aflossen. Afgezien van de moeilijkheden, die eene dergelijke wijze van kapitaalverschaffing voor de overheid overigens wellicht zou meebrengen (in ieder geval zou niet een zoo groot fonds ter beschikling staan), is deze wijze van financieren practisch niet mogelijk, nu bij Koninklijk Besluit van 17 Augustus 1917 (No. 78) is beslist, dat een hesluit van

1) Dr.. G. Th. J. Delfgauw, De Grondpolitiek van de Gemeente $\Lambda$ msterdam 